\title{
SEQUENTIAL RELEASE OF ACROSOMAL MEMBRANES AND ACROSOMAL ENZYMES OF RAM SPERMATOZOA
}

\author{
P. N. SRIVASTAVA, ${ }^{*}$ J. F. MUNNELL, $\dagger$ C. H. YANG* AND \\ C. W. FOLEY
}

Reproduction Research Laboratory, Department of Biochemistry* and Departments of Anatomy and Radiology $\dagger$ and Physiology and Pharmacology, $\ddagger$ College of Veterinary Medicine, University of Georgia, Athens, Georgia 30602, U.S.A.

\section{(Received 9th March 1973)}

\begin{abstract}
Summary. A method involving the treatment of ram spermatozoa with $\mathrm{MgCl}_{2}$ followed by Hyamine 2389 and Triton X-100 is described, which gave selective removal of the acrosomal membranes and acrosomal enzymes. The effect on the individual membranes of ram spermatozoa was evaluated by electron microscopy. Treatment with $\mathrm{MgCl}_{2}$ removed or altered the integrity of the plasma and outer acrosomal membranes, allowing the release of material from the acrosome. The inner acrosomal membrane and the electron-dense material of the equatorial segment were frequently unaffected by this treatment. Subsequent treatment of these spermatozoa with Hyamine and Triton removed the inner acrosomal membrane and the electron-dense material from the equatorial segment. The $\mathrm{MgCl}_{2}$ extract contained acrosomal proteinases and hyaluronidase. The detergent extract contained sperm neuraminidase.

The specific activities and yields of the enzymes obtained in the $\mathrm{MgCl}_{2}$ step were much higher than those of the enzymes obtained by the detergent treatment. Slight alterations in the conditions of the treatment had different effects on the acrosomal membranes in that one or more of the membranes were removed or altered in varying proportions resulting in the release of one or more enzymes. Only the plasma membrane and the acrosome appeared to be affected by these treatments as selected mitochondrial enzymes were not detectable in the extracts.
\end{abstract}

\section{INTRODUCTION}

A need has existed for some time to develop a method for the sequential removal of the plasma membrane and acrosomal enzymes from spermatozoa under the mildest possible conditions. Pedersen (1972) described a method based on rapid freezing of human spermatozoa in liquid nitrogen and subsequent thawing for extracting the anterior segment of the acrosome and most of the equatorial segment. This method, however, yields a total acrosomal extract containing enzymes associated with all the acrosomal components and 
is, therefore, similar to the methods of Hartree \& Srivastava (1965) and Srivastava, Zaneveld \& Williams (1970). Any acrosomal enzymes other than the trypsin-like enzyme which could be extracted by Pedersen's method were not reported. Recently, Srivastava (1973a) described a two-step method involving treatment of the washed spermatozoa of ram and rabbit first with $\mathrm{MgCl}_{2}$ followed by the detergents, Hyamine 2389 and Triton X-100, for the sequential removal of the acrosomal enzymes. By this method, most of the trypsin-like enzyme was extracted by $\mathrm{MgCl}_{2}$. Polakoski, Zaneveld \& Williams (1972) gave the trypsin-like enzyme (Stambaugh \& Buckley, 1969) the designation 'acrosin', because it hydrolyses benzoyl-L-arginine ethyl ester preferentially and has certain properties in common with trypsin and plasmin yet is different from both (Zaneveld, Polakoski \& Williams, 1972).

In all previous studies except that of Pedersen, the extent of the acrosomal removal was determined by light microscope examination of samples of spermatozoa stained with Giemsa. By these means, the effect of treatments on the individual membranes, namely, the plasma membrane (PM), the outer acrosomal membrane (OAM) and the inner acrosomal membrane (IAM), could not be ascertained. This paper describes the sequential extraction method in detail, the effect of treatments on the individual sperm membranes as determined by the transmission electron microscope and the enzymes extracted.

\section{Chemicals}

\section{MATERIALS AND METHODS}

Hyamine 2389 (methyl dodecyl benzyl trimethylammonium chloride and methyl dodecyl xylene-bis-trimethylammonium chloride) and Triton X-100 were obtained from Rohm \& Haas Co. Benzoyl arginine ethyl ester (BAEE) was bought from Mann Research Laboratories. Azocoll (general proteolytic substrate) 50-100 mesh, Lot No. 010154 was purchased from Calbiochem. Hyaluronic acid, Lot $51 \mathrm{C}-2270$ potassium salt, Grade III-P from human umbilical cord, was purchased from Sigma Chemical Co.

\section{Collection and washing of semen}

Ram semen was collected from eight to twelve rams by electroejaculation. Semen was pooled immediately following collection and processing was initiated within $1 \mathrm{hr}$ from the time of the first collection.

The standard washing procedure was described earlier (Srivastava, 1973a). To establish the effect of buffer, the spermatozoa were washed with KrebsRinger phosphate (KRP), 0.15 $\mathrm{M}-\mathrm{NaCl}$ and $0.05 \mathrm{M}$-tris buffer, $\mathrm{pH} 7.4$.

\section{Selective removal of the acrosomal membranes}

The standard procedure for the treatment of ram spermatozoa washed in $0.05 \mathrm{M}$-tris $\mathrm{HCl}$ buffer, $\mathrm{pH} 7 \cdot 4$, either at $20^{\circ} \mathrm{C}$ (Method A), or at $2^{\circ} \mathrm{C}$ (Method B), first with $\mathrm{MgCl}_{2}$ and subsequently with Hyamine and Triton, was the same as described earlier (Srivastava, 1973a) and was followed for the experiments described in this paper. The optimum conditions for the removal of acrosomes by $\mathrm{MgCl}_{2}$ were determined by treating washed spermatozoa with different 
concentrations of $\mathrm{MgCl}_{2}$ for varying periods of time in $0.05 \mathrm{M}$-tris maleate buffer, $\mathrm{pH} 6 \cdot 1$. Hartree \& Srivastava (1965) reported that acrosomes were best removed at this $\mathrm{pH}$.

\section{Light microscopy}

The percentage of acrosomes removed was first determined by examining the samples stained with Giemsa according to established methods (Hartree \& Srivastava, 1965; Srivastava, 1973a). At least 100 spermatozoa were counted

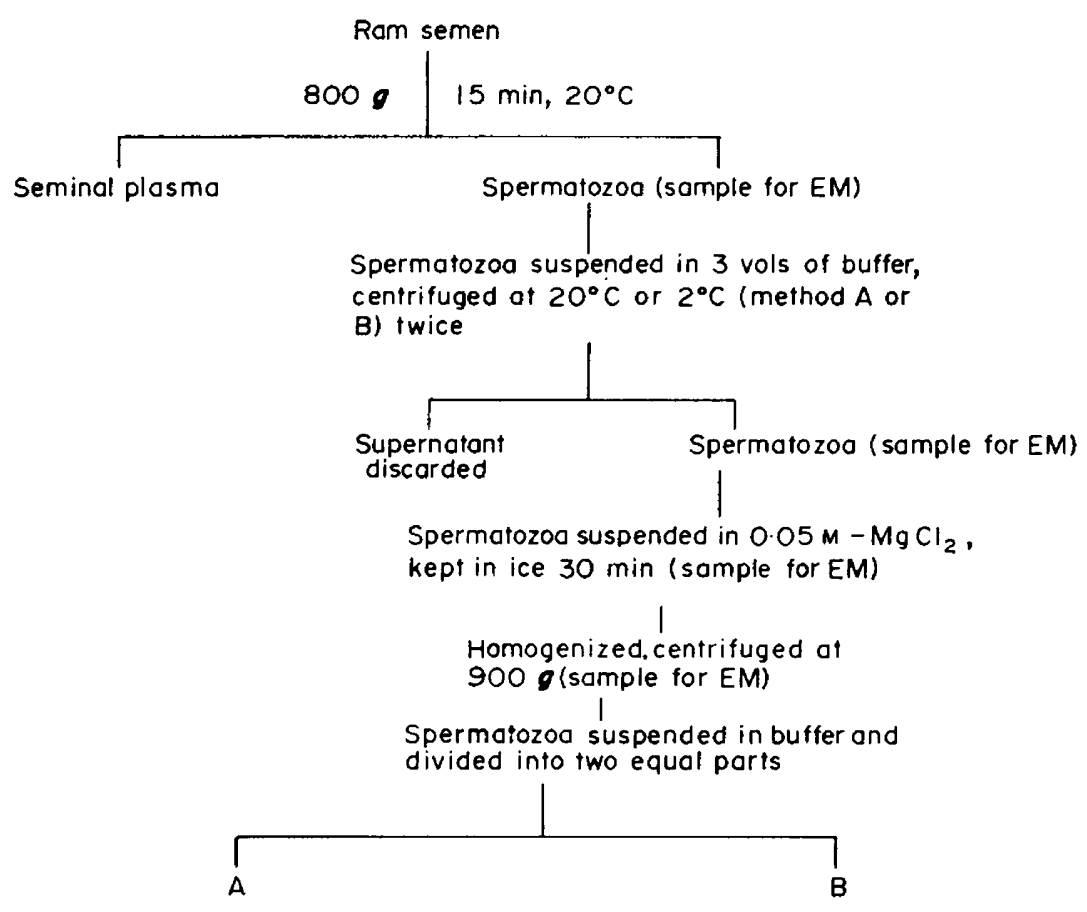

Add equal volume of

Add equal volume of $0.1 \%$ $0.1 \%$ Hyamine Hyamine $+0.1 \%$ Triton

$37^{\circ} \mathrm{C}, 90 \mathrm{~min}$, centrifuge

Sample for EM

Somple for EM

Text-Fig. 1. Treatment of ram spermatozoa for electron microscopy.

at random to arrive at an estimation of the percentage of acrosomes affected. Spermatozoa which did not stain in the acrosomal region were regarded as having lost their acrosomes.

\section{Electron microscopy}

Samples to be examined by means of the electron microscope were obtained following each of the steps outlined in Text-fig. 1. Samples of semen were centrifuged at $900 \mathrm{~g}$ for $15 \mathrm{~min}$, the supernatant was removed, and the pellet was immersed in a fixative solution. This solution consisted of $2.5 \%$ glutaraldehyde in $0.1 \mathrm{M}$-sodium cacodylate buffer $(\mathrm{pH} 7 \cdot 2)$ with the addition of $\mathrm{CaCl}_{2}(0.5$ 
$\mathrm{mg} / \mathrm{ml}$ ) to the final solution. After 10 to $15 \mathrm{~min}$ in the fixative, the pellet was broken up and the smaller pieces were allowed to remain in the solution for a total of $1 \mathrm{hr}$. The fixative was replaced by an equal amount of the buffer containing $10 \%$ sucrose. The pellets remained in this solution overnight. After being placed for $1 \mathrm{hr}$ in a $1 \%$ osmium tetroxide solution buffered to $\mathrm{pH}$ 7.2 by a modification of Dalton's buffer (Richardson, 1962), the samples were dehydrated in ascending concentrations of methanol, and embedded in Epon 812 by the method described by Luft (1961). Sections were cut by means of glass knives with a Sorvall MT-2 ultramicrotome, mounted on 300 mesh copper grids and stained with a $0.5 \%$ solution of uranyl acetate $(8 \mathrm{~min})$ followed by lead citrate $(6 \mathrm{~min})$ as described by Reynolds (1963). The sections were examined by means of a RCA-EMU4A electron microscope.

In grids representing each of the samples, the first fifty sperm heads encountered which were cut in a plane which resulted in the inclusion of both the main portion of the acrosomal cap and the postacrosomal region were examined for the presence or absence of PM, OAM and IAM. Care was taken to ensure that this count was confined to a single section in order to avoid repetition.

\section{Sperm enzyme assay}

Acrosomal proteinases were determined by (1) hydrolysis of BAEE as described earlier (Srivastava, 1973a). The acrosin inhibitor was dissociated from the enzyme by incubation at $\mathrm{pH} 3.0(\mathrm{HCl})$ at $37^{\circ} \mathrm{C}$ for $10 \mathrm{~min}$ and the activity was followed at pH 8.0 as above (Polakoski, Zaneveld \& Williams, 1971). Using BAEE as substrate, one unit represents a change of 1 optical density unit at $253 \mathrm{~nm}$ in $1 \mathrm{~min}$ at room temperature.

Hydrolysis of azocoll (proteinase) was determined by a modification of the method described by Jackson \& Matsueda (1970). The modification is based on the information contained in Calbiochem Document No. 3805 (Cat. No. 19493). Acrosomal proteinase (100 to $300 \mu \mathrm{g}$ protein) in $0.2 \mathrm{ml}$ was incubated with $10 \mathrm{mg}$ azocoll in $0.05 \mathrm{~m}$-tris $\mathrm{HCl}$ buffer containing $0.05 \mathrm{M}^{-\mathrm{CaCl}_{2}}, \mathrm{pH}$ $9 \cdot 0$, in a total volume of $3 \mathrm{ml}$ at $37^{\circ} \mathrm{C}$ for $10 \mathrm{~min}$ and was then filtered. The absorbancy of the filtrate was measured at $520 \mathrm{~nm}$ against the substrate blank. One unit of activity using azocoll as substrate was that amount of enzyme required to increase the optical density by 0.001 absorbance units in $1 \mathrm{~min}$.

Hyaluronidase was estimated colorimetrically by a modification of the method of Aronson \& Davidson (1967), as described earlier (Srivastava, 1973a). One unit of hyaluronidase activity was that amount of enzyme which liberated $1 \mu \mathrm{mol} \mathrm{N}$-acetylglucosamine at $37^{\circ} \mathrm{C}$ in $1 \mathrm{~min}$. According to this modification, 1 unit was equivalent to 29 units of the National Formulary Standard.

Protein was estimated by the method of Lowry, Rosebrough, Farr \& Randall (1951), using bovine serum albumin as standard.

\section{RESULTS}

The spermatozoa washed in $\mathrm{KRP}, \mathrm{NaCl}$ or tris- $\mathrm{HCl}$ buffers at $20^{\circ} \mathrm{C}$ showed no damage to the acrosome when they were compared with unwashed spermatozoa under the light microscope. When spermatozoa were washed at $2^{\circ} \mathrm{C}$ 
in tris-HCl buffer, however, approximately $10 \%$ of the spermatozoa lost their acrosomes and some membranous fragments, presumably from the PM, were scattered in the field. No such difference was noted when spermatozoa were washed at $2^{\circ} \mathrm{C}$ in $\mathrm{KRP}$ or NaCl. It seems that a combination of the low temperature and hypotonicity of tris- $\mathrm{HCl}$ buffer $(0.05 \mathrm{~m})$ altered the integrity of the PM.

Table 1. Effect of varying molarity of $\mathrm{MgCl}_{2}$ and period of incubation on removal of acrosomes from ram spermatozoa

\begin{tabular}{c|c|c}
\hline $\begin{array}{c}\mathrm{MgCl}_{2} \\
(\mathrm{M})^{*}\end{array}$ & $\begin{array}{c}\text { Period of incubation } \\
\text { in ice (min) }\end{array}$ & $\begin{array}{c}\% \text { Acrosomes } \\
\text { removed } \dagger\end{array}$ \\
\cline { 2 - 3 } 0.05 & 15 & 73 \\
& 30 & 77 \\
0.1 & 60 & 79 \\
& 15 & 76 \\
0.3 & 30 & 59 \\
& 15 & 50 \\
& 30 & 45 \\
0.5 & 60 & 40 \\
& 15 & 49 \\
& 30 & 51 \\
\hline
\end{tabular}

* $\mathrm{MgCl}_{2}$ was dissolved in $0.05 \mathrm{M}$-tris maleate buffer, $\mathrm{pH} 6 \cdot 1$.

$\dagger$ Percentages are based on loss of ability to stain with Giemsa (see text).

Table 2. Effects of treatment with $\mathrm{MgCl}_{2}$ and detergents on ram sperm acrosomes as determined by light microscopy

\begin{tabular}{|c|c|c|c|c|c|c|}
\hline \multirow[b]{2}{*}{ Method } & \multirow{2}{*}{$\begin{array}{l}\text { Average } \\
\text { number of } \\
\text { samples }\end{array}$} & \multicolumn{5}{|c|}{$\%$ Acrosomes removed ${ }^{*}$} \\
\hline & & $\begin{array}{l}\text { Washed } \\
\text { sperm. }\end{array}$ & $\begin{array}{l}\text { Incubation } \\
\text { with } \mathrm{MgCl}_{2} \\
\text { at } 37^{\circ} \mathrm{C}\end{array}$ & $\begin{array}{c}\text { Incubation } \\
\text { with } \mathrm{MgCl}_{2} \\
\text { at } 2^{\circ} \mathrm{C}, 30 \mathrm{~min}\end{array}$ & Homogenization & $\begin{array}{c}\text { Hyamine } \\
\text { plus } \\
\text { Triton }\end{array}$ \\
\hline $\begin{array}{l}\text { A } \\
\text { B }\end{array}$ & $\begin{array}{l}5 \\
5\end{array}$ & $\begin{array}{r}5 \\
10\end{array}$ & $\begin{array}{l}20 \\
45\end{array}$ & $\begin{array}{l}25 \\
65\end{array}$ & $\begin{array}{l}40 \\
75\end{array}$ & $\begin{array}{l}95 \\
95\end{array}$ \\
\hline
\end{tabular}

* Based on loss of staining in the acrosomal region by Giemsa stain (Srivastava, 1973a).

Maximal removal of the acrosomes was obtained by incubating spermatozoa in $0.05 \mathrm{M}-\mathrm{MgCl}_{2}$ for $30 \mathrm{~min}$ in an ice-bath or with $0.1 \mathrm{M}-\mathrm{MgCl}_{2}$ for $15 \mathrm{~min}$. As the molarity of $\mathrm{MgCl}_{2}$ increased from 0.1 to $0.5 \mathrm{M}$, the percentage of acrosomes removed was significantly reduced (Table 1 ). Treatment, with $0.05 \mathrm{M}-\mathrm{MgCl}_{2}$ for $30 \mathrm{~min}$ in ice was, therefore, adopted as the standard procedure.

The results in Table 2 showed that spermatozoa treated by Methods A and $\mathrm{B}$ differed significantly from each other in the percentage of acrosomes removed by $\mathrm{MgCl}_{2}$ treatment. 


\section{Morphology of treated spermatozoa}

Table 3 summarizes the total effect on each of the acrosomal membranes obtained by Methods $\mathrm{A}$ and $\mathrm{B}$ up to the $\mathrm{MgCl}_{2}$ step. Treatment with the combination of Hyamine and Triton produced identical results regardless of the methods and, therefore, the results were combined. Since $\mathrm{MgCl}_{2}$ removed only $54 \%$ of the OAM by Method A as compared to $80 \%$ of the OAM removed by Method B, the spermatozoa subjected to Method A were observed in greater detail as mere vesiculation and fragmentation of the acrosomal membranes allowed release of the soluble acrosomal enzymes.

Table 3. Effect of various treatments of ram spermatozoa as indicated by electron microscopy

\begin{tabular}{l|c|c|c|c|c}
\hline \multicolumn{1}{c|}{ Treatment } & Method & $\begin{array}{c}\text { All membranes } \\
\text { present } \\
(\%)\end{array}$ & $\begin{array}{c}\text { PM fragmented } \\
\text { or lost } \\
(\%)\end{array}$ & $\begin{array}{c}\text { OAM fragmented } \\
\text { or lost } \\
(\%)\end{array}$ & $\begin{array}{c}\text { IAM fragmented } \\
\text { or lost } \\
(\%)\end{array}$ \\
\hline None & - & 70 & 30 & 2 & 0 \\
Sperm. washed & A & 70 & 30 & 2 & 0 \\
$\begin{array}{c}\text { Washed sperm. } \\
\text { treated with } \\
\text { MgCl }_{2} \text { and } \\
\text { homogenized }\end{array}$ & B & 24 & 76 & 20 & 0 \\
$\begin{array}{c}\text { Subsequent } \\
\text { treatment of } \\
\text { sperm. after } \\
\text { MgCl }_{2}\end{array}$ & B & 0 & 100 & 54 & 6 \\
\hline
\end{tabular}

For abbreviations, see text.

Method A. A large percentage ( $70 \%)$ of the spermatozoa in both the unwashed and washed samples appeared normal with all membranes intact (Pl. 1, Fig. 1). Fragmentation and actual loss of the PM was noted in $30 \%$ of the spermatozoa. The OAM was seldom affected. The spermatozoon shown in Pl. 1, Fig. 1, also served as a control for the technique of fixation and staining of samples for electron microscopy.

Following treatment with $\mathrm{MgCl}_{2}$ and homogenization, complete PMs over the head region were rarely found. In such samples, fragmentation and loss of

\section{EXPLANATION OF PLATE 1}

The bar in each figure indicates $1 \mu \mathrm{m}$.

Fig. 1. Ram spermatozoon washed in $0.05 \mathrm{~m}$-tris $\mathrm{HCl}$ buffer $\left(\mathrm{pH} \mathrm{7.4)}\right.$ at $20^{\circ} \mathrm{C}$. All membranes are intact. The plasma membrane (PM) is separated from the outer acrosomal membrane (OAM) by a space of variable size, probably artifact. IAM=inner acrosomal membrane; $\mathrm{ES}=$ equatorial segment of acrosome.

FIG. 2. Ram spermatozoon following treatment with $\mathrm{MgCl}_{2}$. The $\mathrm{PM}$ is missing and the $\mathrm{OAM}$ has an irregular contour. Note the difference in density of the material contained in the acrosomal cap compared to that in the ES (arrows).

FIG. 3. Ram spermatozoa after $\mathbf{M g C l}_{2}$ treatment. Spermatozoon $\mathrm{A}$ has an acrosome of even contour containing dense material. The OAMs of spermatozoa $B$ and $C$ are irregular and a difference in the density of the contents of the acrosomal cap can be noted when compared to that of $A$ or to that of the equatorial segments.

FIG. 4. Ram spermatozoon with vesiculation of the OAM. The continuity of the OAM with the PM can be noted at both poles of the acrosomal cap (arrows). Dense material is retained in the equatorial segment. 
PLATE 1



(Facing p. 368) 


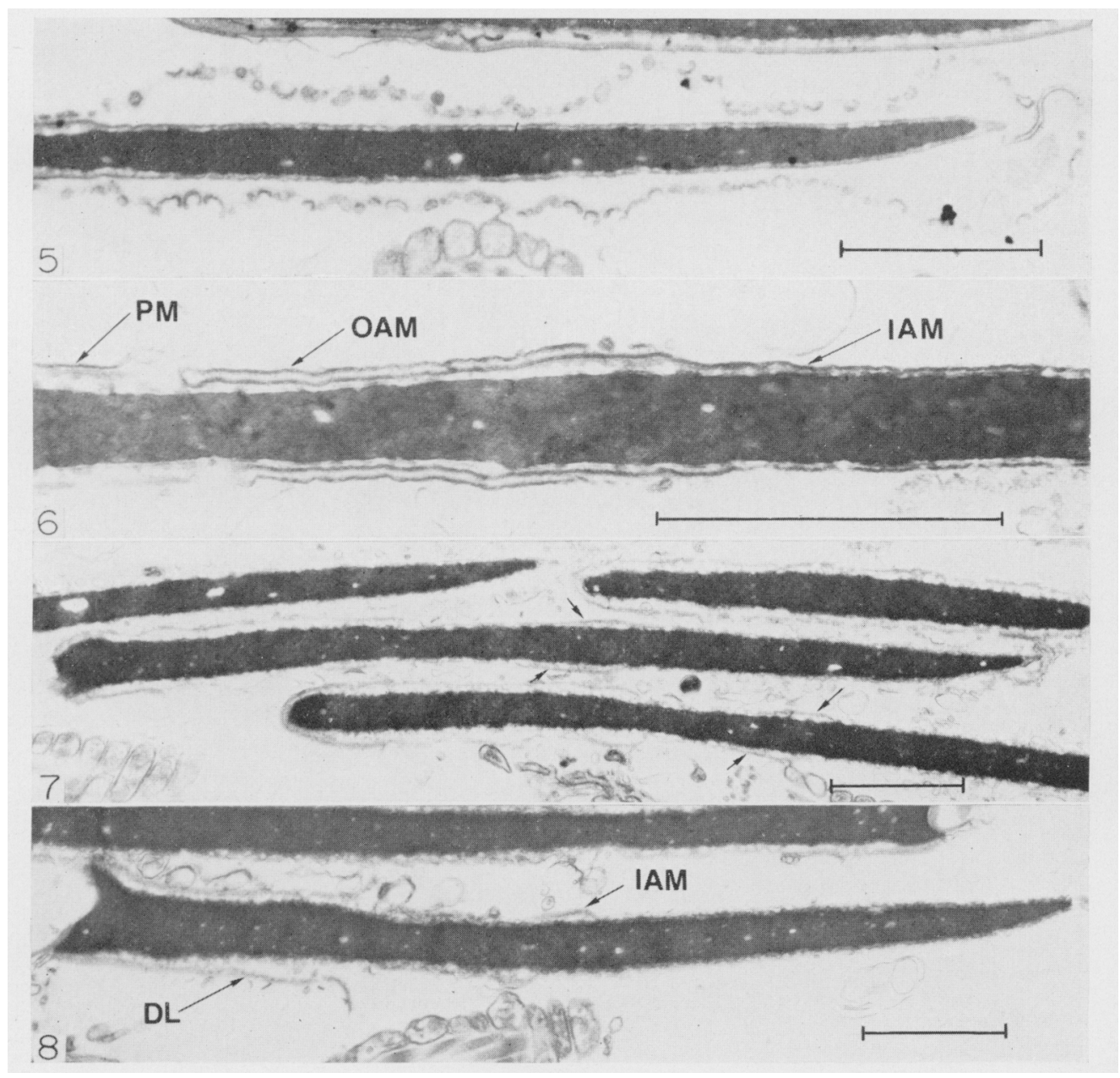

The bar in each figure indicates $1 \mu \mathrm{m}$.

Fig. 5. Ram spermatozoon showing extrcme vesiculation of the OAM.

FIG. 6. The equatorial region of a ram spermatozoon. The PM has been lost except over the postacrosomal region and the OAM has been lost except over the equatorial segment. The dense contents of the ES appear also to have been lost. The IAM remains intact.

Fig. 7. Ram spermatozoa after detergent treatment. All the membranes over the sperm head have been disrupted and only remnants of the IAM remain in the cquatorial region (arrows).

FIG. 8. Ram spermatozoa after detergent treatment. Remants of the IAM and the postacrosomal dense lamina (1)I,) are visible. 
the OAM was noted. An uneven contour of the OAM was noted in many spermatozoa in which this membrane remained intact (Pl. 1, Figs 2 and 3). The space between the OAM and the IAM was somewhat enlarged and the density of the acrosomal content was less in spermatozoa exhibiting this effect. The acrosomal content in the equatorial region retained a density comparable to that seen in intact spermatozoa.

In other spermatozoa in which the OAM was discontinuous, its place was taken by a row of membranous vesicles (Pl. 1, Fig. 4 and Pl. 2, Fig. 5). Occasionally, direct continuation between the OAM and the PM was noted (Pl. 1, Fig. 4). This usually occurred at the apical and equatorial ends of the acrosomal caps. Often the entire OAM was fragmented or lost but in many spermatozoa, it remained intact in the equatorial segment of the cap.

Method $B$. Washing resulted in $76 \%$ of the spermatozoa having discontinuous or missing plasma membranes. Irregularity in the contour of the OAM with a decreased density of the acrosomal contents was more pronounced. Similarly, an increased fragmentation or loss of the OAM was seen in these spermatozoa after treatment with $\mathrm{MgCl}_{2}$. There was also some loss of density in the contents of the equatorial segment (Pl. 2, Fig. 6).

Detergent treatment. After exposure to Hyamine, fragmentation and loss of the IAM was noted in $38 \%$ of the spermatozoa. Following treatment with HyamineTriton, $76 \%$ of the spermatozoa exhibited changes affecting all three membranes. The irregular contour and vesiculation seen in the OAM were not observed in the IAM. The membrane appeared to be discontinuous or completely lost. In many cases when the IAM was affected, both acrosomal membranes in the equatorial segment were also fragmented or lost, but often portions of the IAM remained in this region (Pl. 2, Figs 7 and 8). The PM of the sperm head in these samples as well as in those treated with $\mathrm{MgCl}_{2}$ alone often persisted in the postacrosomal region, although it was missing in the mid-piece. Some remnants of the post-acrosomal dense lamina were present in most cases (Pl. 2, Fig. 8).

\section{Enzyme activities}

The distribution of enzymes is shown in Table 4. The sum of proteins extractable by $\mathrm{MgCl}_{2}$ and detergents separately was equal to the total extractable protein by the sequential method. On this basis, the spermatozoa treated by Methods $\mathrm{A}$ and $\mathrm{B}$ showed interesting differences in the amounts of enzyme extracted. By Method $\mathrm{A}, \mathrm{MgCl}_{2}$ extracted $42 \%$ of the protein, $84 \%$ of the acrosin, $38 \%$ of the azocoll proteinase and $64 \%$ of the hyaluronidase. Using Method $\mathrm{B}, \mathrm{MgCl}_{2}$ extracted $63 \%$ of the protein, $90 \%$ of the acrosin, $70 \%$ of the azocoll proteinase and $87 \%$ of the hyaluronidase. The subsequent combined Hyamine and Triton extract contained the remainder of the above enzymes and all of the sperm neuraminidase (Srivastava et al., 1970). The control experiments in which spermatozoa were treated with all the steps of Methods A and $\mathrm{B}$, omitting $\mathrm{MgCl}_{2}$ and detergents, caused an insignificant release of enzymes.

Although $\mathrm{MgCl}_{2}$ yielded acrosin of much higher specific activity than that of the subsequent detergent extract, the specific activity of azocoll proteinase in the two steps was not very different (Table 4). On preincubation at $\mathrm{pH} 3$ to 
Table 4. Enzyme activities of the ram sperm acrosomal extracts prepared by the sequential method

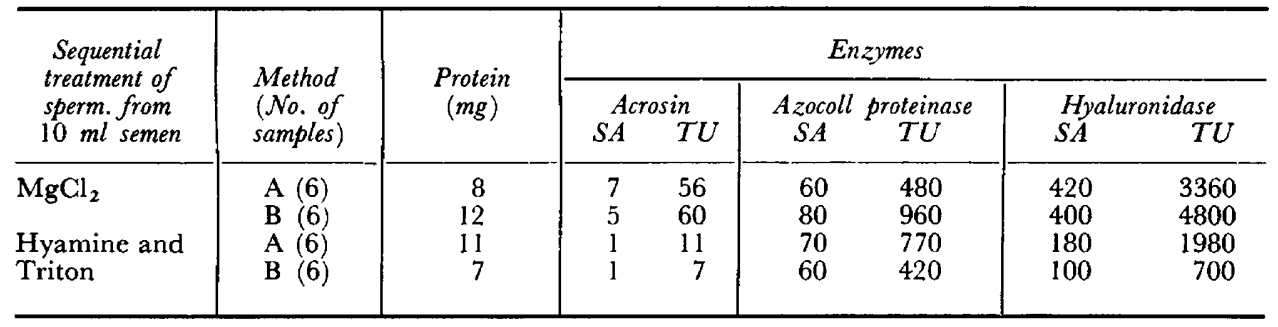

$\mathrm{SA}=$ specific activity; $\mathrm{TU}=$ total units.

dissociate the acrosin-acrosin complex, the $\mathrm{MgCl}_{2}$ extract lost $30 \%$ of its acrosin and $40 \%$ of its azocoll proteinase activity, while the acrosin activity of the subsequent detergent extract was increased by $50 \%$ and the azocoll proteinase activity remained unchanged.

\section{DISCUSSION}

These results provide new methods for selective removal of the plasma and acrosomal membranes as well as the enzymes associated with these structural components.

A comparison of enzyme activities with morphological changes suggested possible localization of the enzymes. The activities of acrosomal proteinases on two different substrates, BAEE and azocoll, are considered the functions of two different enzymes, acrosin and azocoll proteinase, respectively. Since azocoll is a non-specific substrate for proteolytic enzymes, it may contain arginyl and lysyl peptide bonds which will be split by acrosin. Recent findings in this laboratory, however, have shown that pure acrosin hydrolyses azocoll very slowly (K. L. Polakoski, personal communication). The observed hydrolysis of azocoll must, therefore, be due to yet another enzyme tentatively designated as the azocoll proteinase (Srivastava \& Foley, 1973).

The decrease in azocoll proteinase and acrosin in $\mathrm{MgCl}_{2}$ extracts preincubated at $\mathrm{pH} 3$ followed by the increase in acrosin in the subsequent detergent extract implies that the remainder of acrosin extractable by detergents and an inhibitor of acrosin solubilized by detergents possibly from the residual $\mathrm{PM}$ or OAM, not removed by previous $\mathrm{MgCl}_{2}$ treatment, formed an acrosinacrosin inhibitor complex. Such a complex is dissociated at $\mathrm{pH} 3$ giving rise to enhancement of acrosin activity (Polakoski et al., 1971). The reason for decrease in the acrosin activity of the $\mathrm{MgCl}_{2}$ extract on preincubation at $\mathrm{pH} 3$ is not known. However, the observed decrease suggests that, at least in this species, the enzyme does not form a complex with its inhibitor and for that reason acrosin is perhaps less stable at this $\mathrm{pH}$. On the other hand, Zaneveld, Polakoski \& Williams (1973) observed that acrosin extracted from ram spermatozoa by detergent treatment alone showed an increase in activity from 0.25 to $0.42 \mathrm{U}$ on preincubation at $\mathrm{pH} 3$ indicating that the inhibitor and the enzyme were extracted together. 
A comparison of the morphological observations with the results of enzyme assay suggests that the enzyme predominant in the $\mathrm{MgCl}_{2}$ extract could be located between the PM and OAM or within the acrosome. Washing at $2^{\circ} \mathrm{C}$ removes or damages the PM in nearly all spermatozoa but the corona-penetrating enzyme (Zaneveld \& Williams, 1970; Srivastava, 1973a), acrosin, pH 3-labile azocoll proteinase, hyaluronidase and aryl sulphatase (our unpublished results) are not lost but are subsequently recovered in the $\mathrm{MgCl}_{2}$ extract. These enzymes must, therefore, be localized within the acrosome and released upon vesiculation, fragmentation or complete loss of the OAM by $\mathrm{MgCl}_{2}$ (Table 4). Sperm neuraminidase, and the yet uncharacterized enzyme, $\mathrm{pH}$ 3stable azocoll proteinase, which are extracted by the subsequent detergent treatment must be localized in the IAM or the equatorial segment. Some cross-contamination is possible at each step as a small amount of the acrosomal membranes not removed by $\mathrm{MgCl}_{2}$ would eventually be removed during subsequent treatment with detergents. It is also conceivable that some of the enyzmes bound to the IAM might be extracted by $\mathrm{MgCl}_{2}$ even though the membrane appears to remain intact. We failed to detect any sperm neuraminidase activity in $\mathrm{MgCl}_{2}$ extracts, possibly because the amount of the enzyme was only a small fraction of that extractable by the subsequent treatment with Hyamine and Triton.

In support of his method for isolating acrosomal material, Pedersen (1972) states, 'The use of $\mathrm{NaOH}$ and Hyamine caused complete removal of the acrosome but with extensive extraction of all segments of the tail. There was also considerable extraction of nuclear material,' but no evidence is presented for this. In our sequential method, even after treatment with $\mathrm{MgCl}_{2}$, detergents did not cause damage to the postacrosomal region of the spermatozoon (cf. Pl. 1, Figs 2 and 3; Pl. 2, Figs 7 and 8).

The absence of glucose-6-phosphate dehydrogenase and cytochrome $\mathrm{G}$ in the $\mathrm{MgCl}_{2}$ extract indicated no contamination from mitochondrial enzymes. Allison \& Hartree (1970) and Zaneveld, Gould, Humphreys \& Williams (1971) were also able to detect only negligible amounts of various mitochondrial enzymes in the acrosomal extracts of ram and rabbit spermatozoa prepared by the detergent treatment. Hartree \& Srivastava (1965) and Allison \& Hartree (1970) found insignificant contamination from DNA in the acrosomal extract of ram spermatozoa prepared by the use of Hyamine.

The physiological significance in terms of sperm penetration through cellular investments of the ovum is not clear from these studies. The vesiculation and fragmentation of the PM and the OAM after treatment with $\mathrm{MgCl}_{2}$ (Method A) has some morphological resemblance to the initial stages of the acrosome reaction (Bedford, 1970). Such changes may permit the release of hyaluronidase and aryl sulphatases which together may be involved in the penetration of the cumulus, as suggested by Allison \& Hartree (1970). The corona-penetrating enzyme extractable by $\mathrm{MgCl}_{2}$ is probably released on the breakdown of the OAM. The zona-lytic enzymes are supposed to be associated with the IAM or the equatorial segment (Bedford, 1970; Yanagimachi \& Teichman, 1972). Therefore, the subsequent detergent extract which removes the IAM and the electron-dense material from the equatorial segment should 
dissolve the zona. Srivastava (1973b) has shown that the $\mathrm{MgCl}_{2}$ extract of rabbit and ram spermatozoa disperses the corona and the detergent extracts dissolve the zona pellucida of the rabbit ovum. These studies, therefore, provide some experimental evidence that the zona-lytic enzyme(s) is indeed located at the IAM or the equatorial segment.

\section{ACKNOWLEDGMENTS}

The authors thank Dr William L. Williams for his constructive criticism of the manuscript. The authors are also grateful to Mrs Diane Fitzgerald, Mrs Pam Witaszek, Mr Larry K. Williams and Mr James Tyner for their skilful technical assistance. The research was supported by Contract NIH-70-2147 and NIH Research Grant 1 PO1 HD-0589-01.

\section{REFERENCES}

Allison, A. C. \& Hartree, E. F. (1970) Lysosomal enzymes in the acrosome and their possible rôle in fertilization. J. Reprod. Fert. 21, 501.

Aronson, N. A., JR \& Davidson, E. A. (1967) Lysosomal hyaluronidase from rat liver. F. biol. Chem. 242, 437.

Bedford, J. M. (1970) Sperm capacitation and fertilization in mammals. Biol. Reprod., Suppl. 2, 128.

Hartree, E. F. \& SRivastava, P. N. (1965) Chemical composition of the acrosomes of ram spermatozoa. F. Reprod. Fert. 9, 47.

Jackson, R. L. \& Matsueda, G. R. (1970) Myxobacter-AL-1-protease. In: Methods In Enzymology, Vol. 19, p. 592, Eds. G. E. Perlmann and L.. Lorand. Academic Press, New York and London.

Lowry, O. H., Rosebrovgh, W. J., FarR, A. L. \& Randall, R. J. (1951) Protein measurement with the Folin phenol reagent. F. biol. Chem. 193, 265.

LuFT, J. (1961) Improvements in epoxy resin embedding methods. 7. biophys. biochem. Cytol. 9, 409.

Pedersen, H. (1972) The acrosome of the human spermatozoon: a new method for its extraction, and an analysis of its trypsin-like enzyme activity. F. Reprod. Fert. 31, 99.

Polakoski, K. L., Zaneveld, L. J. D. \& Williams, W. L. (1971) An acrosin-acrosin inhibitor complex in ejaculated boar sperm. Biochem. biophys. Res. Commun. 45, 381.

Polakoski, K. L., Zaneveld, L. J. D. \& Williams, W. L. (1972) Purification of a proteolytic enzyme from rabbit acrosomes. Biol. Reprod. 6, 23.

Reynolds, E. S. (1963) The use of lead citrate at a high pH as an electron-opaque stain in electron microscopy. J. Cell Biol. 17, 208.

Richardson, K. C. (1962) The fine structure of autonomic nerve endings in smooth muscle of rat vas deferens. F. Anat. 96, 427.

Srivastava, P. N. (1973a) Removal of acrosomes of ram and rabbit spermatozoa. F. Reprod. Fert. 33, 323.

SRivastava, P. N. (1973b) Location of the zona lysin. Biol. Reprod. 9, 84.

SRIvastava, P. N. \& Foley, C. W. (1973) Multiple proteolytic enzymes from mammalian sperm acrosomes. Fedn Proc. Fedn Am. Socs exp. Biol. 32, 284.

SRivastava, P. N., Zaneveld, L. J. D. \& Williams, W. L. (1970) Mammalian sperm acrosomal neuraminidase. Biochem. biophys. Res. Commun. 39, 575.

Stambaugh, R. \& Buckley, J. (1969) Identification and subcellular localization of the enzymes effecting penetration of the zona pellucida by rabbit spermatozoa. F. Reprod. Fert. 19, 423.

Yanagimachi, R. \& Teichman, R. J. (1972) Cytochemical demonstration of acrosomal proteinase in mammalian and avian spermatozoa by a silver proteinate method. Biol. Reprod. 6, 87.

Zaneveld, L. J. D., Gould, K. G., Humphreys, W. J. \& Williams, W. L. (1971) Scanning electron microscopy of mammalian spermatozoa. $\mathcal{F}$. Reprod. Med. 6, 13.

Zaneveld, L. J. D., Polakoski, K. L. \& Williams, W. L. (1972) Properties of a proteolytic enzyme from rabbit sperm acrosomes. Biol. Reprod. 6, 40.

Zaneveld, L. J. D., Polakoski, K. L. \& Williams, W. L. (1973) A proteinase and proteinase inhibitor of mammalian sperm acrosomes. Biol. Reprod. (in press).

Zaneveld, L. J. D. \& Williams, W. L. (1970) A sperm enzyme that disperses the corona radiata and its inhibition by decapacitation factor. Biol. Reprod. 2, 363. 